\title{
Gammaglobulin treatment and anti-IgA antibodies in IgA-deficient patients
}

\author{
JUKKA KOISTINEN， MARJATTA HEIKKILÄ，JUHANI LEIKOLA
}

British Medical fournal, 1978, 2, 923-924

\section{Summary and conclusions}

Antibodies to IgA may cause severe anaphylactic reactions during blood transfusions. Tests for anti-IgA antibodies were carried out on six patients with IgA deficiency (five of whom also had hypogammaglobulinaemia) who had received continuous gammaglobulin treatment for chronic or recurrent infections for three to eight years. Three patients had minute amounts of IgA, and three had none (less than $0.01 \mu \mathrm{g} / \mathrm{ml}$ ). Only one patient had anti-IgA. Her antibody titre did not change during treatment. No patient had any untoward effects of treatment, which relieved the symptoms of infection in every case.

IgA determinations should be performed by more accurate methods than radial immunodiffusion when evaluating the risks of giving gammaglobulin to patients with hypogammaglobulinaemia and IgA deficiency. Probably the stimulus provided by intramuscular gammaglobulin in such patients is insufficient for the formation of anti-IgA antibody.

\section{Introduction}

Much attention has been paid to the risks of giving gammaglobulin to patients with hypogammaglobulinaemia and IgA deficiency ${ }^{1-5}$ because antibodies to IgA may cause severe anaphylactic reactions. Regularly administered gammaglobulin, however, reduces the frequency and severity of the chronic or recurrent infections that occur in some of these patients, and thus the indications for treatment must be weighed against the possible risks of immunisation against IgA.

We have investigated a group of patients with hypogammaglobulinaemia and IgA deficiency receiving gammaglobulin to see if they formed anti-IgA.

Finnish Red Cross Blood Transfusion Service, SF-00310 Helsinki 31, Finland

JUKKA KOISTINEN, MD, director of blood collection

MARJATTA HEIKKILÄ, CANDMED, research associate

JUHANI LEIKOLA, MD, director of central laboratory

\section{Patients and methods}

During April 1972 to May 1977 samples from 122 IgA-deficient patients were examined for anti-IgA antibodies. Of these, six patients, who had been receiving gammaglobulin for three to eight years for chronic or recurrent respiratory infections and whose serum had been examined repeatedly for anti-IgA, were selected for the study (see table). Two were children. The dose of gammaglobulin (16\%) varied from 5 to $20 \mathrm{ml}$ and was given intramuscularly every three or four weeks in the outpatient department. Most patients had had intermissions in treatment lasting two to three months. All had been hospitalised several times because of their infections.

In all cases the IgA deficiency had originally been detected by immunoelectrophoresis and quantitative immunoglobulin determinations during investigations for the recurrent infections. When the samples were sent to us for anti-IgA determination we also measured the IgA concentrations by means of a haemagglutination inhibition assay $^{6}$ and competitive enzyme immunoassay. ${ }^{7}$ These two methods have detection limits of about 0.5 and $0.01 \mu \mathrm{g} / \mathrm{ml}$ respectively and are thus about 20 and 1000 times more sensitive than Mancini's single radial immunodiffusion. ${ }^{89}$ The enzyme (alkaline phosphatase) was conjugated to isolated IgA by the glutaraldehyde method of Avrameas. ${ }^{10}$

Anti-IgA antibodies were sought by the passive haemagglutination method of Gold and Fudenberg, ${ }^{11}$ chromic chloride being used as coupling agent. Human $\mathrm{O} \mathrm{Rh}$-positive erythrocytes were coated with isolated myeloma IgA proteins belonging to the subclass IgAl and the allotype $A_{2} m(1)$ of the subclass IgA2. Proteins of allotype $A_{2} m(2)$ of the subclass IgA2 were not available. The IgA proteins had been isolated by the caprylic acid precipitation method of Fine and Steinbuch.12 Each sample was tested with at least four different proteins representing both subclasses. Microtitre plates with Ubottom wells were used in the agglutination reaction. ${ }^{9}$

\section{Results}

All six patients were found to be IgA deficient by the conventional immunodiffusion techniques. When the haemagglutination assay and competitive enzyme immunoassay were performed, however, three patients were shown to have IgA in their serum. In three other samples no IgA was found. In five patients IgG and, to a less extent, IgM were also decreased (table).

Antibodies to IgA were found in only one patient (case 4) despite many of the samples being tested with as many as eight isolated IgA proteins. The titre persisted at $1 / 2000$ throughout the years of gammaglobulin treatment (figure). The antibody reacted equally well with all the proteins and was thus class-specific.

The treatment was well tolerated in all cases. Two of the patients (with no antibodies to IgA) had mild local pain and a transient rash

Details of IgA-deficient patients given gammaglobulin treatment

\begin{tabular}{|c|c|c|c|c|c|c|c|c|}
\hline \multirow{2}{*}{$\begin{array}{l}\text { Case } \\
\text { No }\end{array}$} & \multirow{2}{*}{$\begin{array}{l}\text { Age and } \\
\text { sex }\end{array}$} & \multicolumn{3}{|c|}{ Serum immunoglobulin concentrations* } & \multirow{2}{*}{ Anti-IgA } & \multirow{2}{*}{$\begin{array}{c}\text { Year } \\
\text { gammaglobulin } \\
\text { treatment } \\
\text { started }\end{array}$} & \multirow{2}{*}{ Diagnosis } & \multirow{2}{*}{ Comments } \\
\hline & & $\underset{(\mu \mathrm{g} / \mathrm{ml})}{\operatorname{IgA}}$ & $\underset{(\mathrm{g} / \mathbf{l})}{\mathrm{IgG}}$ & $\underset{(\mathbf{g} / 1)}{\operatorname{IgM}}$ & & & & \\
\hline $\begin{array}{l}1 \\
2 \\
3 \\
4\end{array}$ & $\begin{aligned} 8 \mathrm{~F} \\
8 \mathrm{~F} \\
22 \mathrm{M} \\
46 \mathrm{~F}\end{aligned}$ & $\begin{array}{l}<0.01 \\
<0.01 \\
1.5 \\
<0.01\end{array}$ & $\begin{array}{c}10 \cdot 5 \\
2 \cdot 6-5 \cdot 7 \\
2 \cdot 0 \\
6 \cdot 5-13 \cdot 0\end{array}$ & $\begin{array}{c}0 \cdot 4 \\
0 \cdot 13-0 \cdot 25 \\
<0.07 \\
0 \cdot 6-1 \cdot 0\end{array}$ & $\begin{array}{l}\text { No } \\
\text { No } \\
\text { No } \\
\text { Yes }\end{array}$ & $\begin{array}{l}1971 \\
1970 \\
1969 \\
1969\end{array}$ & $\begin{array}{l}\text { Recurrent respiratory infections } \\
\text { Recurrent respiratory infections } \\
\text { Recurrent respiratory infections } \\
\text { Recurrent respiratory infections; } \\
\text { anaemia; malabsorption; }\end{array}$ & $\begin{array}{l}\text { Allergy to penicillin } \\
\text { IgA deficiency in brother } \\
\text { Several blood transfusions } \\
\text { Allergy to penicillin }\end{array}$ \\
\hline 5 & $47 M$ & $3 \cdot 3$ & $<1.0$ & $0 \cdot 25$ & No & 1964 & $\begin{array}{l}\text { recurrent keratitis } \\
\text { Recurrent respiratory infections; }\end{array}$ & Died of sepsis, 1977 \\
\hline 6 & $47 \mathrm{M}$ & $5 \cdot 4$ & $2 \cdot 7-3 \cdot 5$ & $0-2 \cdot 9$ & No & 1974 & $\begin{array}{l}\text { Recurrent respiratory infections; } \\
\text { bronchiectasis }\end{array}$ & Allergy to penicillin \\
\hline
\end{tabular}

*Normal ranges for adults: IgA $1 \cdot 5-5 \cdot 2 \mathrm{~g} / \mathrm{l} ; \operatorname{IgG} 8 \cdot 0-19 \cdot 0 \mathrm{~g} / 1 ; \operatorname{IgM} 0 \cdot 3-1 \cdot 4 \mathrm{~g} / \mathrm{l}$. 


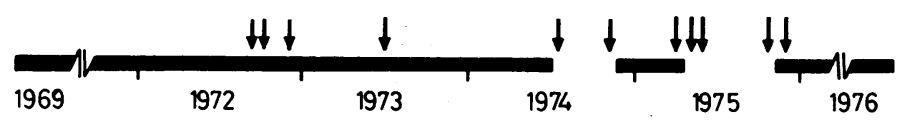

Case 4. Treatment with intramuscular gammaglobulin ( discovery of IgA deficiency in 1969, and timing of tests for anti-IgA antibodies (arrowed)

after the injections. The patient with anti-IgA antibodies had no side effects.

\section{Discussion}

Regular intramuscular administration of gammaglobulin apparently does not stimulate anti-IgA formation in patients with hypogammaglobulinaemia and IgA deficiency despite the presence of small amounts of IgA, which invariably occurs in commercial preparations. ${ }^{13}$ This finding is important, since gammaglobulin is beneficial against recurrent infections in patients with hypogammaglobulinaemia.

Three of our patients had some IgA in their serum as measured with the haemagglutination inhibition assay and enzyme immunoassay and were thus unable to form class-specific antibodies to IgA owing to immunological tolerance. We think that it is essential to use more sensitive methods than immunodiffusion for determining IgA concentrations before a person is considered to be lacking IgA and at risk of forming dangerous antibodies to IgA.

Low serum IgG and IgM concentrations, which we found in five patients, may indicate poor general immune response, which would accord with the inability to form anti-IgA antibodies. The antibody titre in one of the patients, whose IgG and IgM concentrations were normal, remained at the same level throughout the follow-up period. This is compatible with our earlier experience-namely, that the titre of class-specific anti-IgA antibodies in serum remains relatively constant.

We thank Ms Annikki Sarnesto (Orion Diagnostica, Helsinki, Finland) for conjugating IgA with alkaline phosphatase. This study was funded in part by a grant (to JK) from the Finnish Medical Foundation Duodecim.

\section{References}

1 Ammann, A J, and Fudenberg, H H, Basic and Clinical Immunology, p 342. Los Altos, California, Lange Medical Publications, 1976.

2 Vyas, G N, Perkins, H A, and Fudenberg, H H, Lancet, 1968, 2, 312.

${ }^{3}$ Schmidt, A P, Taswell, H F, and Gleich, G J, New England fournal of Medicine, 1969, 280, 188.

4 Leikola, J, et al, Blood, 1973, 42, 111.

5 Bjerrum, O J, and Jersild, C, Vox Sanguinis, 1971, 21, 411.

${ }^{6}$ Koistinen, J, and Fudenberg, H H, ASM Manual of Clinical Immunology, p 562. Washington, DC, American Society for Microbiology, 1976.

${ }^{7}$ Engvall, E, Johnsson, K, and Perlmann, P, Biochimica et Biophysica Acta, $1971,251,427$.

${ }^{8}$ Heikkilä, M, and Koistinen, J, XV Congress of the International Society of Blood Transfusion, Paris, July 23-29, 1978.

9 Koistinen, J, Vox Sanguinis, 1975, 29, 192.

10 Avrameas, S, Immunochemistry, 1969, 6, 43.

11 Gold, E R, and Fudenberg, H H, fournal of Immunology, 1967, 99, 859.

12 Fine, J M, and Steinbuch, M, Revue Européenne d'Etudes Cliniques et Biologiques, 1970, 15, 1115.

13 Wadsworth, C, and Hanson, L A, Scandinavian fournal of Immunology, $1976,5,15$.

(Accepted 14 August 1978)

\title{
CONDENSED REPORT
}

\section{Pupillary signs in diabetic autonomic neuropathy}

\author{
S E SMITH, SHIRLEY A SMITH, P M BROWN, C FOX, P H SÖNKSEN
}

British Medical fournal, 1978, 2, 92×-927

\section{Summary and conclusions}

Pupillary function was investigated in 36 insulindependent diabetics and 36 controls matched for age and sex. About half of the diabetics had evidence of peripheral somatic or autonomic neuropathy, or both. The diabetic patients had abnormally small pupil diameters in the dark and less fluctuation in pupil size (hippus) during continuous illumination than the controls. They also had reduced reflex responses to light flashes of an inten-

\section{St Thomas's Hospital Medical School, London SE1 7EH}

S E SMITH, DM, PHD, reader in applied pharmacology and therapeutics SHIRLEY A SMITH, MA, PHD, research fellow, department of pharmacology P M BROWN, MRCP, research fellow, department of medicine

C FOX, MRCP, research fellow (now senior medical registrar, Royal Devon and Exeter Hospital, Exeter)

P H SÖNKSEN, MD, FRCP, reader in medicine sity adjusted for individual retinal sensitivities. The pupillary findings were compared with results of five tests of cardiovascular function and five tests of peripheral sensory and motor nerve function.

Almost all the patients with autonomic neuropathy had pupillary signs, which we therefore conclude are a common manifestation of diabetic autonomic neuropathy.

\section{Introduction}

Dysfunctions of the cardiovascular, gastrointestinal, sweating, and genitourinary systems constitute the well-known manifestations of diabetic autonomic neuropathy. ${ }^{1}$ The effect on the pupil, however, has not been well defined, and pupillary abnormality has been described as both $a$ rare $^{2}{ }^{3}$ and a frequent ${ }^{4} 5$ complication. This abnormality, sometimes called an Argyll Robertson pupil, ${ }^{\circ}$ has been reported to comprise a reduced diameter at rest and poor, sluggish responses to light. Reduced light reflexes may, however, be the result of diminished afferent input due to retinopathy. In the study reported here pupillary function was investigated in detail and the influence of reduced 